ISSN 0103-5150

Fisioter. Mov., Curitiba, v. 26, n. 3, p. 503-513, jul./set. 2013

Licenciado sob uma Licença Creative Commons

\title{
Effects of a physical therapy program on quality of life among community-dwelling elderly women: randomized-controlled trial
}

\author{
Efeitos de um programa de fisioterapia sobre a qualidade de vida de \\ mulheres idosas da comunidade: estudo randomizado controlado
}

\author{
Mariana Chaves Aveiro $^{[a]}$, Patricia Driusso ${ }^{[b]}$, Julia Gianjoppe dos Santos ${ }^{[c]}$, Viviane Dassi Kiyoto ${ }^{[\mathrm{d}]}$, \\ Jorge Oishi ${ }^{[e]}$ \\ [a] PhD, Physical Therapy Professsor at Federal University of São Paulo (Unifesp), Department of Human Movement Sciences, \\ Santos, SP - Brazil, e-mail: mariaveiro@yahoo.com \\ [b] PhD, Physical Therapy Professsor at Federal University of São Carlos (UFSCar), Physical Therapy Department, São Carlos, \\ SP - Brazil, e-mail: pdriusso@ufscar.br \\ [c] PhD student of Physical Therapy Department, Federal University of São Carlos (UFSCar), São Carlos, SP - Brazil, e-mail: \\ julia_gian@hotmail.com \\ [d] Graduated in Physical Therapy, Federal University of São Carlos (UFSCar), São Carlos, SP - Brazil, e-mail: \\ vi_kiyoto@hotmail.com \\ [e] PhD, Statistics Professsor at Federal University of São Carlos (UFSCar), Statistics Department, São Carlos, SP - Brazil, \\ e-mail: djoi@ufscar.br
}

\begin{abstract}
Introdução: Health promotion policies for encouraging elderly to remain active, independent and, effectively have a positive effect on their quality of life. Objective: To verify the effects of a low-intensity group-based physical therapy program on quality of life among community-dwelling elderly women. Materials and methods: It was carried out a randomized controlled trial. Seventeen women (67.8 \pm 4.9 years old) that completed 12-week training program and 10 women ( $68.9 \pm 5.7$ years old) that were included in control group answered the abbreviated version for World Health Organization Quality of life Questionnaire WHOQOL-bref at baseline and after 12 weeks. Exercise group performed stretching, resistance and balance training. Intragroup and intergroup analysis was made using Wilcoxon and Mann-Whitney U tests, respectively. The level of significance used for all comparisons was $5 \%$. Furthermore, it was determined the Reliable
\end{abstract}


Change Index (RCI) as part of JT Method. Results: Exercise group presented a significant improvement for Psychological domain ( $p=0.047$ ) after 12-week physical therapy program. Otherwise, control group presented a significant worsening for overall $(p=0.01)$, physical $(p=0.01)$ and psychological $(p=0.008)$ domains. Exercise group presented two participants with positive reliable change (PRC) for social domain, two participants with PRC for Environment domain. Overall and Physical domain presented three participants with PRC. Psychological domain presented four participants with PRC and one with negative reliable change. Conclusion: A low-intensity group-based physical therapy program may contribute in order to maintain quality of life and improve some psychological aspects among community-dwelling elderly women.

Keywords: Elderly. Physical therapy. Quality of life.

\section{Resumo}

Introduction: Políticas públicas de promoção de saúde contribuem para encorajar o envelhecimento ativo, com independência, e tem efeitos positivos na qualidade de vida da população idosa. Objetivo: Avaliar os efeitos de um programa de treinamento fisioterapia de baixa intensidade, realizado em grupo, sobre a qualidade de vida de mulheres da comunidade. Materiais e métodos: Realizou-se estudo clinico randomizado. Dezessete mulheres (67,8 \pm 4,9 anos de idade) que completaram 12 semanas de treinamento, a dez mulheres (68,9 \pm 5,7 anos de idade) que foram incluídas no grupo controle, responderam a versão abreviada do Questionário de Qualidade de Vida da Organização Mundial de Saúde - WHOQOL-bref. O Grupo Exercício realizou treinamento de flexibilidade, resistência e equilíbrio. Análises intragrupo e intergrupo foram feitas por meio dos testes não paramétricos Wilcoxon e Mann-Whitney U, respectivamente. Foi utilizado um nível de significância de 5\%. Ainda, foi determinado o Índice de Mudança Confiável segundo o Método JT. Resultados: O grupo treinamento apresentou uma melhora significativa para o domínio psicológico ( $p=0,047)$ e o grupo controle apresentou uma piora significativa para o escore geral ( $p=$ $0,01)$ e os domínios físico $(p=0,01)$ e psicológico $(p=0,008)$. Para o grupo de exercícios, no domínio social, duas participantes apresentaram mudança positiva confiável (MPC) e no domínio ambiente, duas participantes. Para o escore geral e domínio físico, três participantes apresentaram MPC. Para o domínio psicológico quatro participantes apresentaram MPC e uma mudança negativa confiável. Conclusão: Um programa de fisioterapia em grupo pode contribuir para manter a qualidade de vida e melhorar especialmente aspectos psicológicos de mulheres idosas da comunidade.

Palavras-chave: Idoso. Fisioterapia. Qualidade de vida.

\section{Introduction}

The proportion of people over 60 years old has been growing more than any other age group. According Geography and Statistics Brazilian Institute (IBGE) (1), projection for relative participation of Brazilian population over 60 years was $9.49 \%$ in 2008 and $29.75 \%$ in 2050 . Life expectancy in the same period may range from 72.78 to 90.97 years. Then, as varied effects of aging as conditions that allow a good quality of life in the elderly may represent great social and scientific importance $(1,2)$.

Ozcan et al. (3) suggested that quality of life does not change with aging but age affects the risk factors for falls. The risk factors for falls (balance, functional mobility, muscle strength, fear of falling) in older adults are associated with quality of life while flexibility and proprioception are not. Strength-generating capacity of muscles is reduced in the elderly people, bringing functional consequences on gait and balance. The weaker muscles of an elderly person may represent an increased risk of a fall and an impaired functional and physical independence (4).

Additionally, health promotion policies for encouraging elderly to remain active, independent and that effectively have a positive effect on their quality of life is a concern for countries through this demographic transition. Brazilian government 
has been already worked to define some public policies for elderly. In 2006, it was approved the Health National Policy for Elderly People (5) that presents as a directive the promotion of active and health aging that refer to maintain functional independence and autonomy throughout aging, allowing the involvement in social, economic, cultural, spiritual, and civic activities. Considering elderly as not as passive citizens, they are agents of your actions in a context that valorizes aspects of community life, identifying potential for physical, social and mental well-being across the life.

In order to understand the effects of a physical therapy program among elderly women the aim of this study was verify the effects of a low-intensity group-based physical therapy program through resistance, balance and coordination training on quality of life among community-dwelling elderly women.

\section{Materials and methods}

This is a randomized-controlled trial that was approved by the Research Ethics Committee of the Federal University of São Carlos (Protocol Number $059 / 2008$ ). The women who took part in the study were informed about the study characteristics, in accordance with Resolution 196/96 from the Brazilian National Health Council. These volunteers provided their written informed consent in order to participate in this study.

\section{Participants}

Participants were invited to take part in this study by radios, newspapers and televisions advertisements. Sixty-one women presented to answer the first interview that investigated inclusion and exclusion criteria. It was included women with 60 years old and older that was living at community. Brazilian Elderly Statute determines that people with 60 years or older could be consider elderly and their rights are protected by its (6).

It was excluded women that used some walking aid, presented low scores at Mini-Mental State Examination $(7,8)$, or presented a doctor report with orthopedics, cardiologic and neurologic impairments. Participants that were not frequent in $75 \%$ sessions were not considered in analyses.
Randomization was carried out through sealed envelope. Each woman chose between two sealed envelopes that designated her for the groups. Participants in the control group did not undergo any training and were instructed to maintain their usual level of physical activity. They were contacted by phone once a month to verify levels of physical activity. They were invited to carry out 12 -week training after the second assessment.

\section{First interview}

The first interview was performed at participant's home or Health-School Ambulatory. In this moment, they were informed about study characteristics. Those who took part in the study provided their written informed consent in order to participate.

They answer a questionnaire in order to investigate socio-demographic and health characteristics. They were questioned about the occurrence of different diseases as encephalic vascular accident, acute myocardial infarction, coronary insufficiency, hypertension arterial, diabetes, dementia, cancer, depression, osteoarthritis, osteoporosis and others.

After that, it was assessment Activities of daily living (ADL) by Brazilian OARS Multidimensional Functional Assessment Questionnaire (BOMFAQ) (9). This is an instrument that evaluates referable difficulties to 15 activities of daily living. They were required about a doctor report that attests good health conditions to take part in the study.

\section{Quality of life questionnaire WHOQOL-bref}

Participants answered the abbreviated version for World Health Organization (WHO) Quality of life Questionnaire - WHOQOL-bref (10) at baseline and after 12 weeks. WHOQOL-bref consists of 26 items. There are two questions about overall quality of life and 24 questions that represent 24 facets of original instrument WHOQOL-100. Each question presents five options to be chosen. Participants receive instructions for check one that approximate about your feelings in the last two weeks. These questions are organized in four domains: physical, psychological, social relationship and environment. Internal consistency was evaluated by Cronbach's coefficient. It 
was $0.91,0.84,0.79,0.69$ and 0.7 for overall, physical, psychological, social relationship and environment domains, respectively (10).

\section{Physical therapy program}

After the baseline assessments, the participants started an exercise program on two days per week for 12 weeks, under the supervision of a physical therapist. They were divided into four small groups according to their own schedule preferences. Each training session consisted of stretching exercises, ankle and knee muscle strengthening and balance training. It was included ludic activities looking for great adherence. Every session were accompanied by music. Blood pressure was verified at the beginning of the session.

Static stretching exercises were carried out for the muscles of the neck, back, arms and legs at the beginning of the session and were followed by the resistance training.

The participants performed ankle plantar flexion by lifting the heels while standing on their feet. Initially, during the adaptation period, the individuals performed four sets of ten bilateral plantar flexion lifts. After six weeks, the participants progressed to four sets of twelve lifts. Ankle dorsiflexion was performed with 0.5 or $1 \mathrm{~kg}$ cuff weights that were wrapped around the front parts of the participant's feet. The participants strengthened their ankle dorsiflexors while standing erect or seated. The dorsiflexion was carried out for the full range of ankle motion for two sets of 10 repetitions.

Knee extension and flexion was carried out for the full range of motion in kinetic opened chain with 0.5 , 1 or $2 \mathrm{~kg}$ ankle cuff weights for two sets of 10 repetitions. Knee extension was performed seated in a chair with 90 degrees of hip flexion and knee flexion was performed standing erect.

In the first session, everybody began every exercise with ankle cuff weights of $0.5 \mathrm{~kg}$. If they carried out easily, they were encouraged to exercise with $1 \mathrm{~kg}$ in the next session. They were argued every week if it was easier carried out the exercises in order to determine increment loads. The physical therapist conducting the session gave one minute rest period between sets to minimize fatigue.

Balance training was followed resistance training. It was followed Silsupadol (11) suggestions that determined the progression in balance training increasing body movements, manipulation and mental tasks and taking off visual reference, closing the eyes.

Dynamic balance training was divided in two parts. In the first moment, they performed lower support base walking. After that, they performed different ludic activities with balls, balloons, obstacles and canes. These activities were also carried out in order to guarantee training adhesion because they were more pleasant. The participants carried out backward and tandem walking, and walked on their heels and tiptoes. It was developed simple and double-tasks. They carried out one motor activity associated with another one mental. They could say different fruit names during a dynamic balance exercise, for example, walking in their tiptoes. It was also developed activities that they performed movements for upper and lower limbs at same time to stimulate coordination.

Initially, in static balance training, it was performed simple tasks with open eyes. They were asked to stand on one leg, their heels and their tiptoes and tandem position. It was permitted hold onto a chair, wall or another apparatus at this moment. Postures were maintained for one minute. After two weeks, they were asked don't hold onto one apparatus during same postures. After 4 weeks they carried out same postures associated to manual or mental tasks or over some foam. After 6 weeks, they were asked close their eyes however it was permitted hold onto a chair or another apparatus. If someone presents great difficulty, she could come back for the anterior level.

Every participant received an exercise manual for fall prevention. It presented specific exercises and some tips for fall prevention. Some doubts could be answered at training sessions.

\section{Data analyses}

All statistical analyses were performed using Statistica statistical software (StatSoft Inc., Tulsa, OK). It was performed using nonparametric tests because it was verified that some variables did not present a normal distribution by Shapiro-Wilk test. The intragroup analysis was carried out using Wilcoxon nonparametric test. Comparison among groups was made using Mann-Whitney U test and Chi-square test. The 
level of significance used for all comparisons was $5 \%$ ( $\mathrm{p} \leq 0.05)$. The data were expressed as means \pm standard deviations.

To measure the practical significance of the data, the effect size and the confidence interval (CI) were calculated. The effect sizes were considered mild if values were smaller than 0.20 ; moderate if values were between 0.25 and 0.75 , and large when values were over 0.80 (12).

Furthermore, it was determined the Reliable Change Index (RCI) proposed by Jacobson and Truax (13) as part of JT Method. Analyses for RCI were carried out considering every participant; however, control and exercise groups were presented in different figures. Reliable change refers to the extent to which the change shown by an individual falls beyond the range which could be attributed to the measurement variability of the instrument itself. The RCI is assessed using a variation on the standard error (SE) of measurement which takes account of two measurements being made (before and after treatment). The formula for the $S E$ of measurement of a difference is $\mathrm{SE}_{\text {dif }}=\mathrm{SD}$ $(\sqrt{ } 2)(\sqrt{ } 1-r)$; where $S D$ is the standard deviation of the baseline observations and, $r$ is the reliability of the measure, generally, Cronbach's coefficient (13-15).

\section{Results}

Figure 1 shows the formation of training and control group since first interview that evaluated inclusion and exclusion criteria. Seventeen women (67.8 \pm 4.9 years old) completed 12 -week training program and ten women ( $68.9 \pm 5.7$ years old) included control group.

Table 1 shows some characteristics for control and exercise group. Groups did not present significant differences to age, weight and height by non-parametric Mann-Whitney U test and activities of daily living (ADL) by Chi-square test. It's also showed the number of participants that presented anyone difficulty, difficulty in 1 to 3,4 to 6 and more than 7 ADL.

Table 2 presents mean and standard deviation at baseline and outcome for Q1 (How would you evaluate your quality of life?), Q2 (How much are you satisfied with your health?), overall and four domains of quality of life questionnaire WHOQOL-bref. Exercise group presented a significant improvement for Psychological domain after 12-week physical therapy program. Otherwise, control group presented a significant worsening for overall, physical and psychological domain with large effect size.

Graph 1 shows scores for Overall of every participant at baseline and outcome and the Reliable Change Index for its.

Graph 2 shows scores for physical, psychological, social relationship and environment domains of every participant at baseline and outcome and the Reliable Change Index for them.

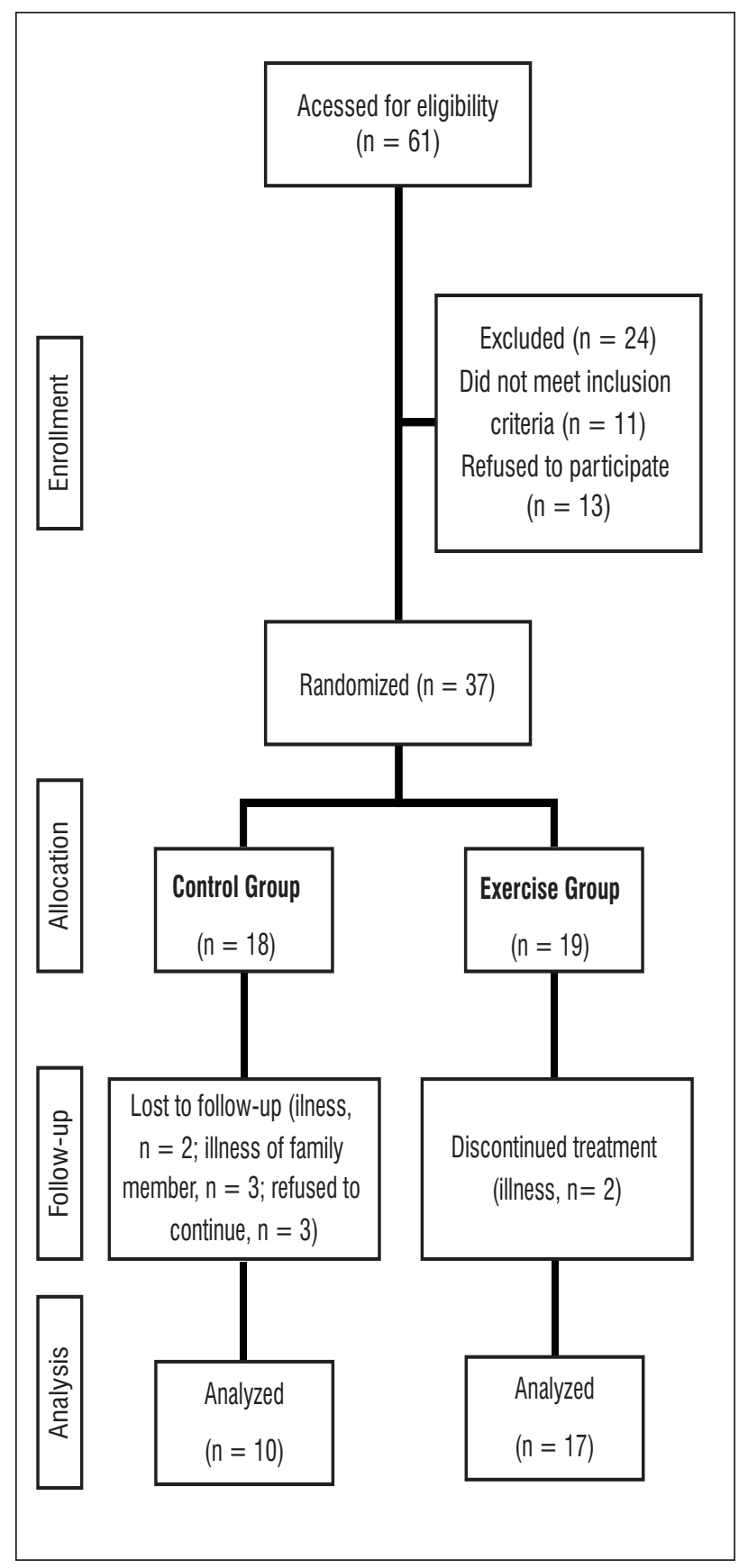

Figure $\mathbf{l}$ - Participants enrollment Source: Research data. 
Table $\mathbf{1}$ - Characteristics of the participants in control and exercise groups

\begin{tabular}{lcc}
\hline & Control $(\mathrm{n}=10)$ & Exercise $(\mathrm{n}=17)$ \\
\hline Age (years) & $68.9 \pm 5.7$ & $67.8 \pm 4.9$ \\
Weight $(\mathrm{kg})$ & $66.0 \pm 11.28$ & $65.12 \pm 8.96$ \\
Height $(\mathrm{m})$ & $1.52 \pm 0.09$ & $1.55 \pm 0.07$ \\
& & \\
anyone difficulty & $1(10 \%)$ & $5(29.4 \%)$ \\
difficulty 1-3 & $8(80 \%)$ & $10(58.8 \%)$ \\
difficulty 4-6 & $1(10 \%)$ & $1(5.9 \%)$ \\
difficulty $>7$ & - & $1(5.9 \%)$ \\
\hline
\end{tabular}

Legend: $A D L=$ Activities of daily living.

Source: Research data.

Note: Data are expressed as mean \pm standard deviation.

Table 2 - Quality of life variables at baseline and outcome for control (C) and exercise (E) groups

\begin{tabular}{|c|c|c|c|c|c|c|c|}
\hline & Groups & Baseline & Outcome & Intragroup & nalysis & Cl & Effect size \\
\hline \multirow{2}{*}{ Question 1} & C & $16.2 \pm 2.2$ & $14.40 \pm 2.07$ & 0.22 & \multirow{2}{*}{0.03 * } & \multirow{2}{*}{-3.76 to -0.86} & \multirow{2}{*}{1.31} \\
\hline & $\mathrm{E}$ & $15.6 \pm 2.3$ & $16.71 \pm 1.57$ & 0.36 & & & \\
\hline \multirow{2}{*}{ Question 2} & C & $15.8 \pm 3.3$ & $15.20 \pm 2.53$ & 0.99 & \multirow{2}{*}{0.28} & \multirow{2}{*}{-3.28 to 0.74} & \multirow{2}{*}{ - } \\
\hline & $E$ & $14.4 \pm 3.4$ & $16.47 \pm 2.4$ & 0.31 & & & \\
\hline \multirow{2}{*}{ Overall } & C & $15.2 \pm 1.4$ & $14.18 \pm 1.89$ & 0.01 * & \multirow{2}{*}{0.006 * } & \multirow{2}{*}{-2.80 to -0.36} & \multirow{2}{*}{1.06} \\
\hline & $\mathrm{E}$ & $15.4 \pm 1.4$ & $15.78 \pm 1.21$ & 0.08 & & & \\
\hline \multirow{2}{*}{ Physical domain } & C & $15.6 \pm 2.0$ & $14.57 \pm 2.14$ & 0.01 * & \multirow{2}{*}{0.02 * } & \multirow{2}{*}{-2.97 to -0.09} & \multirow{2}{*}{0.87} \\
\hline & $E$ & $16.0 \pm 1.4$ & $16.1 \pm 1.49$ & 0.28 & & & \\
\hline \multirow{2}{*}{ Psychological domain } & C & $14.8 \pm 1.7$ & $13.27 \pm 2.42$ & 0.008 * & \multirow{2}{*}{0.009 * } & \multirow{2}{*}{-3.88 to -0.72} & \multirow{2}{*}{1.19} \\
\hline & $E$ & $15.0 \pm 1.9$ & $15.57 \pm 1.58$ & 0.047 * & & & \\
\hline \multirow{2}{*}{ Social domain } & C & $16.20 \pm 2.5$ & $16.20 \pm 3.19$ & 0.13 & \multirow{2}{*}{0.78} & \multirow{2}{*}{-2.28 to 2.20} & \\
\hline & $E$ & $17.4 \pm 2.5$ & $16.24 \pm 2.44$ & 0.96 & & & \\
\hline \multirow{2}{*}{ Environment domain } & C & $14.8 \pm 1.6$ & $13.85 \pm 1.92$ & 0.12 & \multirow{2}{*}{0.04 * } & \multirow{2}{*}{-2.88 to -0.12} & \multirow{2}{*}{0.89} \\
\hline & $\mathrm{E}$ & $14.8 \pm 1.7$ & $15.35 \pm 1.54$ & 0.24 & & & \\
\hline
\end{tabular}

Legend: * = significant; $\mathrm{Cl}=$ confidence interval.

Source: Research data.

Note: Data are expressed as mean \pm standard deviation.

\section{Discussion}

Data analysis through non-parametric statistics tests showed some first results after physical therapy program. However, exercise group have been just showed significant improvement for psychological domain, control group showed a significant worsening for overall, physical and psychological domains; 


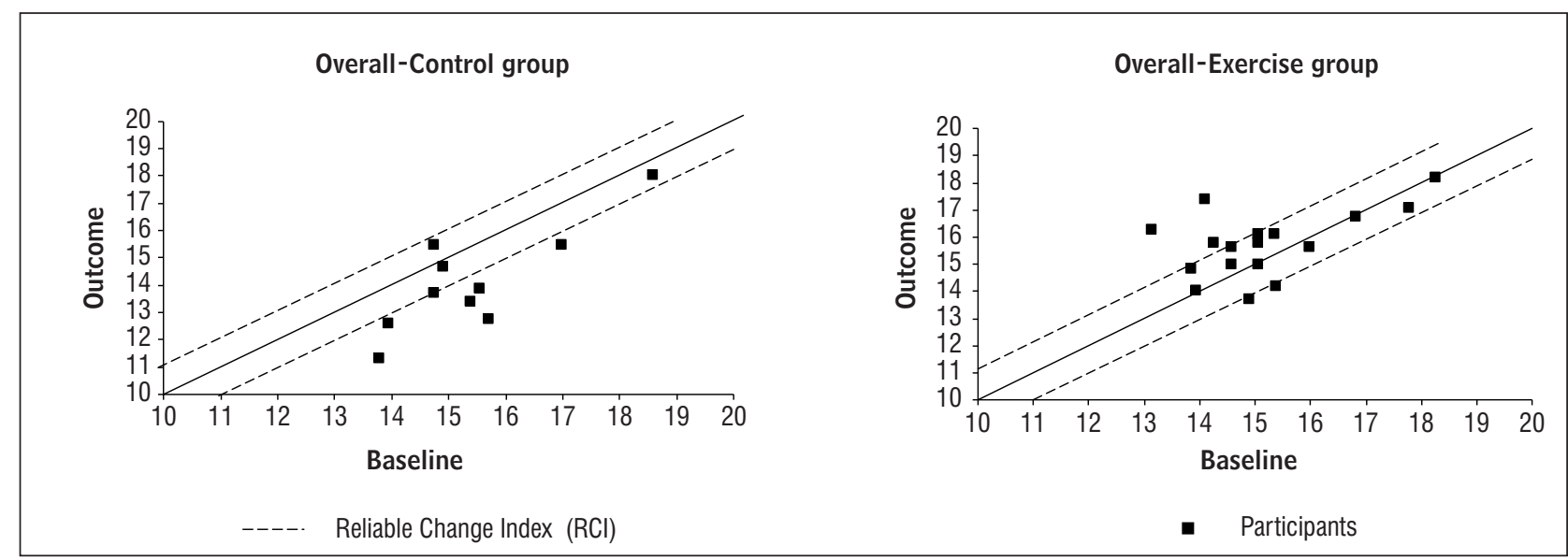

Graph 1 - Reliable Change Index for Overall (WHOQOL-bref) Source: Research data.

it refers the physical therapy program is important to maintain quality of life.

Data analyzed by JT Method (13) bring more information about effects of physical therapy program on quality of life because it presented individual analysis. Reliable Change Index (RCI) permits verify if the difference between pre and post-intervention may be considered reliable, if the change is not related to an error in measurement. In order to show if RCI represents a reliable change, it is used conditions equations: $\mathrm{RCI}>1.96$ represents positive reliable change (PRC); RCI <-1.96 represents negative reliable change (NRC); anyone of this options represents no change (NC). In order to define confidence interval to RCI at graphic representation it is used the equations $\mathrm{y}=\mathrm{x}$ $+1,96 \mathrm{EP}_{\text {dif }}$ and $\mathrm{y}=\mathrm{x}-1,96 \mathrm{EP}_{\text {dif }}$

Pereira et al. (16) used JT Method in order to evaluate Child Behavior Checklist (CBCL) scores of 61 children and teenagers that received treatment for enuresis. The RCI showed that participants, generally, had their scores reduced after the treatment. They also concluded that the JT method is a promising way of data assessment in this area, since it allows more detailed and significant clinical analysis.

Environment and Social Relationship domains did not present significant differences for anyone group. However, RCI shows more details about physical therapy program effects by graphic representation. Scores for these two domains seem to be worse for control group. It was observed for Social Relationship Domain two participants in the exercise group with PRC, and, anyone in the control group. In the Environment domain, it was observed two participants with PRC in the exercise group, and, one with NRC in the control group.

Non-parametric statistics was not also sufficient to identify some improvement in exercise group for overall and physical domains that presented three participants with PRC, and, anyone with NRC. Otherwise, in the control group, it was observed six and three participants with NRC for Overall and Physical Domains, respectively, and, significant worsening by Wilcoxon test.

Psychological domain presented a significant improvement in despite of one participant has been presented NRC. This participant sustained an injury one day before outcome assessments influencing some feelings about depression, anxiety, self-esteem and body image that may prejudice psychological domain. RCI showed to be a good method to analyze interventions on quality of life, since it allowed individual analysis and participants' evolution through the physical therapy program.

It was concluded in the Sguizzatto et al. (17) study that regular physical activity is related to a better quality of life and lower scores for depressive symptoms among elderly women. Psychological factors, as assessed by the Geriatric Depression Scale, had an impact on quality of life assessed through WHOQOLbref (18) since some questions assess this aspect, for example: "What is the frequency that you present negative feelings as bad mood, anger, anxiety and depression?", or, "How much did you find some meaning in your life?".

Generally, there are relevant psychological and social changes among elderly proportionate by 


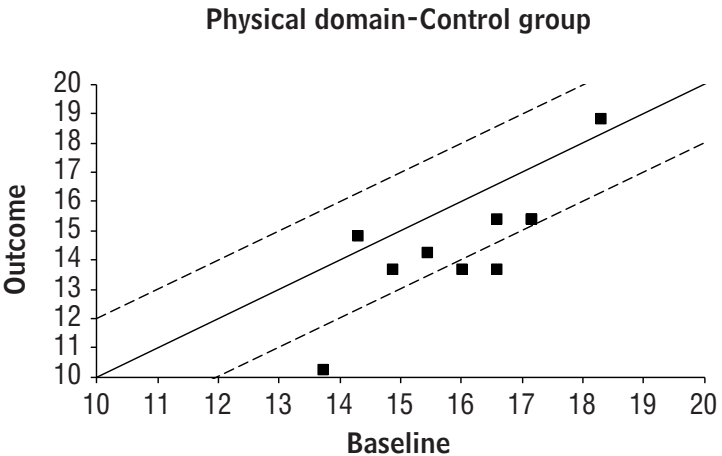

Psychological domain-Control group

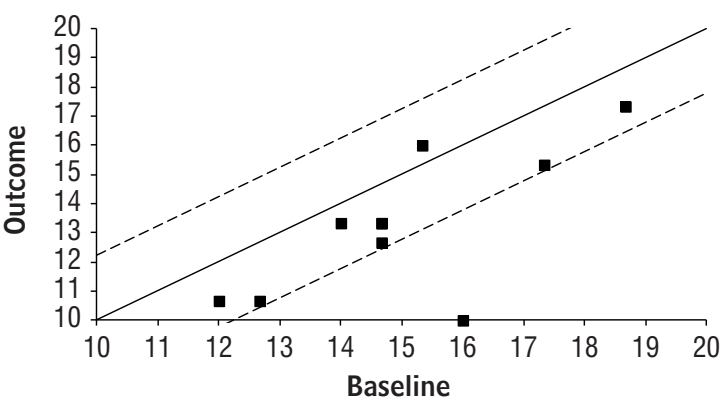

Social domain-Control group

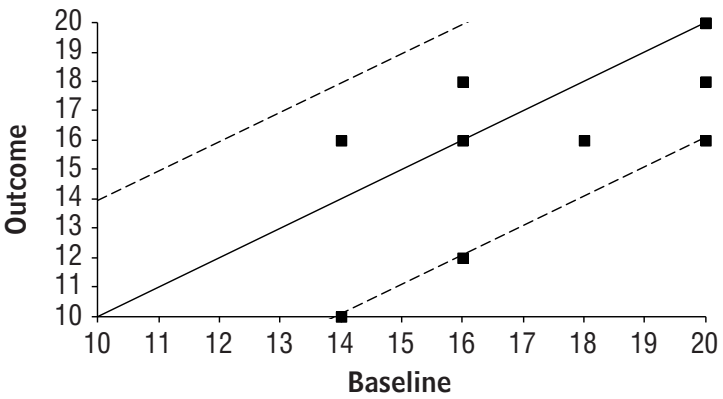

Environment domain-Control group

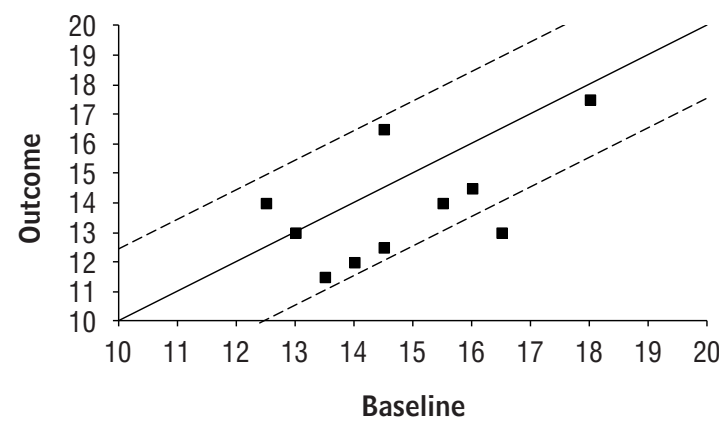

Reliable Change Index (RCl)
Physical domain-Exercise group

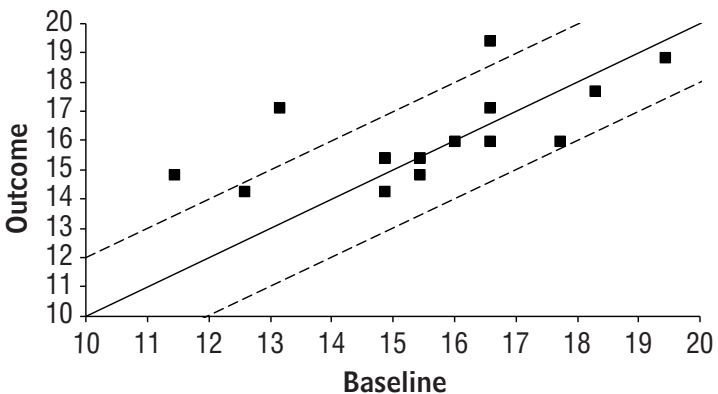

Psychological domain-Exercise group

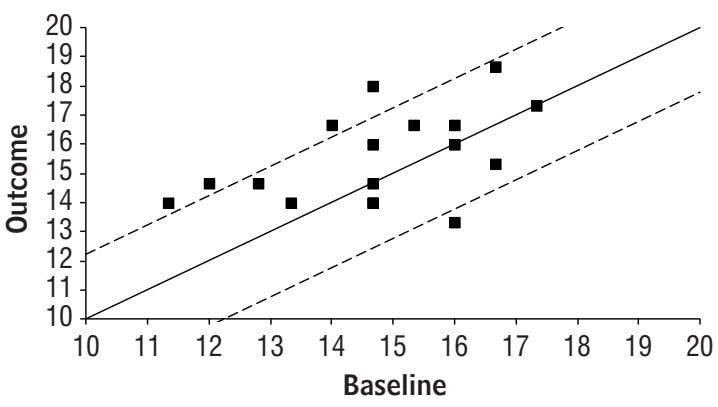

Social domain-Exercise group

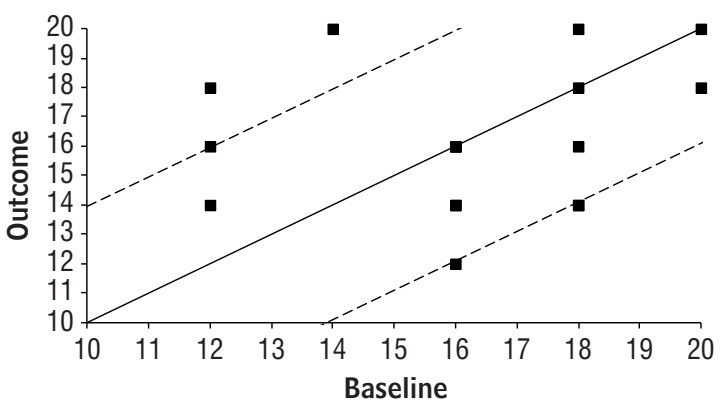

Environment domain-Exercise group

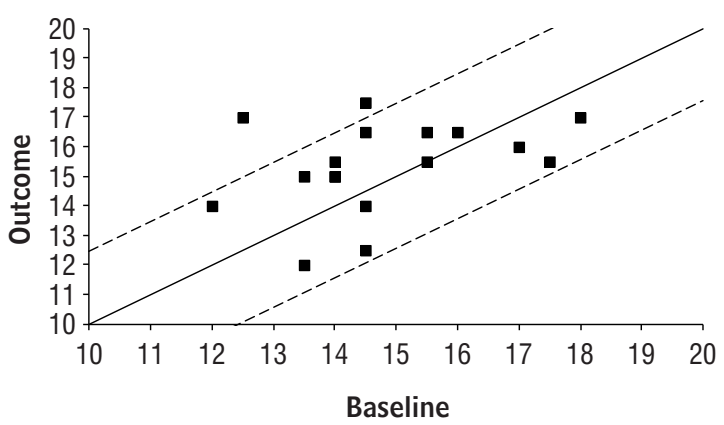

- Participants

Graph 2 - Reliable Change Index for physical, psychological, social relationship and environment domains (WHOQOL-bref) Source: Research data. 
involvement in elderly therapeutic groups; however, in Pereira et al. (19) study, psychological domain presented the lowest significant contribution to quality of life and social domain did not present a significant contribution. During, physical activity sessions, there are some opportunities of social relationship among participants contributing to interchange of experiences and friendships. Physical therapy program brings improvement to functional aspects as an opportunity for a date outside home.

Great influence of physical domain on quality of life scores among elderly people shows the importance of functional capacity as an impact factor to determine the quality of life, specially, among frailty elderly. Functional status presented no influence on the quality of life variable in the analysis models in active elderly (18).

Functional capacity maintenance may be important to quality of life (19) because seems to be related with the capacity to work and entertain until advanced aged (20). Despite of this could be interesting develop exercise programs to decrease risk factors for functional impairment. If it is introduced factors related to social activities, may be easier to organize elderly groups by stimulus of a health and social life through physical, cultural and leisure activities (20).

Binder et al. (21) results revealed that a supervised training for physical frailty elderly may decrease some physical and functional restrictions. Exercise seems improve clinics measures of functional capacity through activities of daily living assessment. Furthermore, it seems prevent a severe frailty that could prejudice the independence. Training characteristics were not different from the present study. It was observed quality of life improvement, evaluated by 36-Item Short-Form Health Survey (SF-36) questionnaire, among elderly that performed flexibility, balance, resistance and endurance training.

High-intensity resistance training among elderly, for 13 weeks, showed an increased functional range and muscle strength through a great recruitment of motor units (22), that may represent the capacity of its to improve quality of life. Carry out physical training has been associated with physical domain from quality of life questionnaire WHOQOL-bref. Elderly people that were carrying out a regular physical activity for five or more times a week presented great scores for this domain (18). Proper physical therapy programs minimizing the risk of falls as muscle strength, balance and flexibility may improve quality of life among elderly (3).
Different studies have already presented some improvement to quality of life after physical training programs. It was observed, for example, significant improvement to quality of life after a balance training program among elderly people with risk of falls (23); after a home training program among elderly women with vertebral fractures (24); and, after a water-based resistance and balance training among women with fibromyalgia (25).

The quality of life outcome at Lin et al. (26) study supported the superiority of home-based exercise training group over the other two interventions, educational group and home safety assessment and modification group among elderly who have recently fallen. Home-based exercise training group consisted of stretching, muscle strengthening, and balance training at increasing levels of difficulty. The training was individualized for each participant, supervised by a physical therapist, and reviewed every two weeks over the study period. It was presented significant improvement to physical, psychological and environment domains of quality of life questionnaire WHOQOL-bref after two months, and, significant improvement for every domain after four months.

Aveiro et al. (27) and Granito et al. (28) also verified significant improvement for variables related to quality of life, through Osteoporosis Assessment Questionnaire (OPAQ), after 12-week training program among women suffering from osteoporosis. Castro et al. (29) compared two programs among elderly women: a multidisciplinary intervention that involved as physical training as music, theatre, environment and citizenship classes; and, a physical intervention of resistance, balance and coordination training. The two programs presented significant improvement for overall, physical and environment WHOQOL-bref domains. It was not observed anyone difference between groups, therefore, these two options may be important to improve quality of life among elderly.

Nevertheless, environment domain has been presented the second influence about quality of life (19); it was not observed significant improvement to exercise group in the present study. Physical training did not promote a safer environment bringing some home alteration during study period.

Generally, the environment may determine individual dependence. Family company, for example, may offer advantages as family support for impairment and disability, otherwise, may promote 
disagreement between members that may contribute to impair elderly self-esteem, emotional state and, consequently, quality of life (19).

Then, physical training program proposed may represent an important finding to be involved in public health policies. However, some studies that assess the sustainability of these actions and services and adhesion among community-dwelling elderly people may be necessary.

In conclusion, a low-intensity group-based physical therapy program involving stretching, resistance and balance training may contribute to maintain quality of life and improve some psychological aspects among community-dwelling elderly women. It may also bring some improvement to social, environment and physical aspects among participants. Furthermore, it is a low-cost effective program that has conditions to be applied in Brazilian Family Health Strategy.

\section{Role of the funding source}

This study was funded by Fundação de Amparo à Pesquisa do Estado de São Paulo (Fapesp - Grant number 2006/06656-1 and 2008/04657-6). The funding sources played no role in the design, conduct, or reporting of the study. The contents of this publication are solely the responsibility of the authors and do not necessarily represent the official view of the funding sources.

\section{References}

1. Instituto Brasileiro de Geografia e Estatística - IBGE. Projeção da população do Brasil por sexo e idade 1980-2050 - revisão 2008. Informação Demográfica e Socioeconômica n. 24, 2008 [cited 14 Jan. 2010]. Available at: http://www.ibge.com.br/home/estatistica/populacao/projecao_da_populacao/2008/ projecao.pdf

2. Fleck MPA, Chachamovich E, Trentini CM. Projeto WHOQOL-OLD: método e resultados de grupos focais no Brasil. Rev Saúde Públ. 2003;37(6):793-9.

3. Ozcan A, Donat H, Geleck N, Ozdirenc M, Karadibak D. The relationship between risk factors for falling and the quality of life in older adults. BMC Public Health. 2005 Aug 26;5:90.
4. Williams GN, Higgins MJ, Lewek MD. Aging skeletal muscle: physiologic changes and the effects of training. Phys Ther. 2002;82(1):62-8.

5. Brasil. Ministério da Saúde. Portaria n. 2528, de 19 de outubro 2006. Aprova a Política Nacional de Saúde da Pessoa Idosa. Diário Oficial [da] República Federativa do Brasil. 2006 out. 19; Seção 1. p. 142-45.

6. Brasil. Ministério da Saúde. Estatuto do Idoso. Brasília: Editora MS; 2003 [cited. 19. Dec]. Available at: http://www.saude.gov.br

7. Folstein MF, Folstein SE, McHugh PR. Mini-Mental state: a practical method for grading the cognitive state of patients for the clinicians. J Psychiatr Res. 1975;12:189-98.

8. Bertolucci PHF, Brucki SMD, Campacci SR, Juliano Y. O mini-exame do estado mental em uma população geral: impacto da escolaridade. Arq Neuropsiquiatr. 1994;52(Suppl. 1):1-7.

9. Ramos LR, Rosa TEC, Oliveira ZMC, Medina MCG, Santos FRG. Perfil do idoso em área metropolitana na região sudeste do Brasil: resultados de inquérito domiciliar. Rev Saúde Públ. 1993;27(2):87-94.

10. Fleck MPA, Louzada S, Xavier M, Chachamovich E, Vieira G, Santos L, et al. Aplicação da versão em português do instrumento abreviado de avaliação da qualidade de vida "WHOQOL-bref". Rev Saúde Públ. 2000;34(2):178-83.

11. Silsupadol P, Siu KC, Shumway-Cook A, Woollacott $\mathrm{MH}$. Training of balance under single- and dual-task conditions in older adults with balance impairment. Phys Ther. 2006;6(2):269-81.

12. Urdan TC. Statistics in plain English. 2nd ed. Mahwah: Lawrence Erlbaum Associates; 2005.

13. Jacobson NS, Truax P. Clinical significance: a statistical approach to defining meaningful change in psychotherapy research. J Consult Clin Psychol. 1991; 59(1):12-19.

14. Evans C, Marginson F, Barkham M. The contribution of reliable and clinically significant change methods to evidence-based mental health. Evid Based Ment Health. 1998;1:70-2.

15. Del Prette ZAP, Del Prette A. Significância clínica e mudança confiável na avaliação de intervenções psicológicas. Psic Teor e Pesq. 2008;24(4):497-505. 
16. Pereira RF, Silvares EFM, Del Prette ZAP. Problemas de comportamento em enuréticos: análise do índice de mudança confiável (IMC). Arq Bras Psicol. 2008;60(3):129-41.

17. Sguizzatto GT, Garcez-Leme LE, Casimiro L. Evaluation of the quality of life among elderly female athletes. Sao Paulo Med J. 2006;124(5):304-5.

18. Alexandre TS, Cordeiro RC, Ramos LR. Factors associated to quality of life in active elderly. Rev Saúde Públ. 2009;43(4):613-21.

19. Pereira RJ, Cotta RMM, Franceschini SCC, Ribeiro RCL, Sampaio RF, Priore SE, et al. Contribuição dos domínios físico, social, psicológico e ambiental para a qualidade de vida global de idosos. Rev Psiquiatr Rio Gd Sul. 2006;28(1):27-38

20. Rosa TEC, Benício MHA, Latorre MRDO, Ramos LR. Fatores determinantes da capacidade funcional entre idosos. Rev Saúde Públ. 2003;37(1):40-8.

21. Binder EF, Schechtman KB, Ehsani AA, Steger-May $\mathrm{K}$, Sinacore DR, Yarasheski KE, et al. Effects of exercise training on frailty in community-dwelling older adults: results of a randomized, controlled trial. J Am Geriatr Soc. 2002;50(12):1921-28.

22. Granacher U, Gruber M, Gollhofer A. Resistance training and neuromuscular performance in seniors. Int J Sports Med. 2009;30:652-57.

23. Steadman J, Donaldson N, Kalra L. A randomized controlled trial of an enhanced balance training program to improve mobility and reduce falls in elderly patients. J Am Geriatr Soc. 2003;51(6):847-52.

24. Papaioannou A, Adachi JD, Winegard K, Ferko N, Parkson W, Cook RJ, et al. Efficacy of home-based exercise for improving quality of life among elderly women with symptomatic osteoporosis-related vertebral fractures. Osteoporos Int. 2003;14(8):677-82.
25. Tomas-Carus P, Gusi N, Hakkinen A, Hakkinen AR, Ortega-Alonso A. Improvements of muscle strength predicted benefits in HRQOL and postural balance in women with fibromyalgia: an 8-month randomized controlled trial. Rheumatology. 2009;48:1147-51.

26. Lin MR, Wolf SL, Hwang HF, Gong SY, Chen CY. A randomized, controlled trial of fall prevention programs and quality of life in older fallers. J Am Geriatr Soc. 2007;55(4):499-506.

27. Aveiro MC, Granito RN, Rennó ACM, Navega MT, Oishi J. Efeitos de um programa de atividade física no equilíbrio e na força muscular do quadríceps em mulheres osteoporóticas visando uma melhoria na qualidade de vida. Rev Bras Ci Mov. 2004;12(3):33-8.

28. Granito RN, Rennó ACM, Aveiro MC, Navega MT, Driusso P, Oishi J. Efeitos de um programa de atividade física na postura hipercifótica torácica, na dorsalgia e na qualidade de vida de mulheres com osteoporose. Rev Bras Fisioter. 2004;8(3):231-7.

29. Castro PC, Tahara N, Rebelatto JR, Driusso P, Aveiro MC, Oishi J. Influência da Universidade Aberta da Terceira Idade (UATI) e do programa de revitalização (REVT) sobre a qualidade de vida de adultos de meia-idade e idosos. Rev Bras Fisioter. 2007;11(6):461-7.

Received: 05/22/2012 Recebido: 22/05/2012

Approved: 01/23/2013 Aprovado: 23/01/2013 